\title{
Genetic inactivation of the Fanconi anemia gene FANCC identified in the hepatocellular carcinoma cell line HuH-7 confers sensitivity towards DNA-interstrand crosslinking agents
}

Andreas Palagyi', Kornelia Neveling², Ursula Plinninger', Andreas Ziesch'1, Bianca-Sabrina Targosz³, Gerald U Denk1,

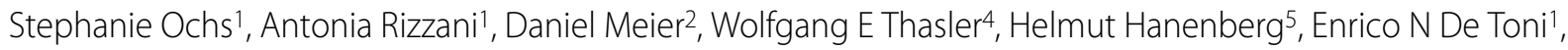
Florian Bassermann³, Claus Schäfer'1, Burkhard Göke' , Detlev Schindler² and Eike Gallmeier*1

\begin{abstract}
Background: Inactivation of the Fanconi anemia (FA) pathway through defects in one of 13 FA genes occurs at low frequency in various solid cancer entities among the general population. As FA pathway inactivation confers a distinct hypersensitivity towards DNA interstrand-crosslinking (ICL)-agents, FA defects represent rational targets for individualized therapeutic strategies. Except for pancreatic cancer, however, the prevalence of FA defects in gastrointestinal (Gl) tumors has not yet been systematically explored.

Results: A panel of Gl cancer cell lines was screened for FA pathway inactivation applying FANCD2 monoubiquitination and FANCD2/RAD51 nuclear focus formation and a newly identified FA pathway-deficient cell line was functionally characterized. The hepatocellular carcinoma (HCC) line HuH-7 was defective in FANCD2 monoubiquitination and FANCD2 nuclear focus formation but proficient in RAD51 focus formation. Gene complementation studies revealed that this proximal FA pathway inactivation was attributable to defective FANCC function in HuH-7 cells. Accordingly, a homozygous inactivating FANCC nonsense mutation (c.553C > T, p.R185X) was identified in HuH-7, resulting in partial transcriptional skipping of exon 6 and leading to the classic cellular FA hypersensitivity phenotype; $\mathrm{HuH}-7$ cells exhibited a strongly reduced proliferation rate and a pronounced G2 cell cycle arrest at distinctly lower concentrations of ICL-agents than a panel of non-isogenic, FA pathway-proficient HCC cell lines. Upon retroviral transduction of HuH-7 cells with FANCC CDNA, FA pathway functions were restored and ICL-hypersensitivity abrogated. Analyses of 18 surgical HCC specimens yielded no further examples for genetic or epigenetic inactivation of FANCC, FANCF, or FANCG in HCC, suggesting a low prevalence of proximal FA pathway inactivation in this tumor type.
\end{abstract}

Conclusions: As the majority of HCC are chemoresistant, assessment of FA pathway function in HCC could identify small subpopulations of patients expected to predictably benefit from individualized treatment protocols using ICLagents.

\section{Background}

Fanconi anemia (FA) is a rare recessive disorder, characterized by congenital skeletal abnormalities, progressive bone marrow failure and an increased cancer susceptibility [1]. The disease is caused by bi-allelic mutations in one

* Correspondence: eike.gallmeier@med.uni-muenchen.de

1 Department of Medicine II, Campus Grosshadern, Ludwig-MaximiliansUniversity, Marchioninistrasse 15, 81377 Munich, Germany Full list of author information is available at the end of the article of 13 FA genes, all of which have now been identified [2]. The FA genes appear to act in a common pathway of DNA damage signalling and DNA remodelling, distal parts of which interact with regulators of cell cycle control and DNA repair, especially the repair of DNA interstrand-crosslinks.

There are three consecutive compartments of the FA pathway [3]. The proximal compartment consists of eight FA proteins (A, B, C, E, F, G, L, and M), which form a 
nuclear FA core complex upon activation. This complex functions as an E3 ligase and mediates the monoubiquitination of FANCD2 [4], which represents the central FA pathway protein. FANCI also becomes monoubiquitinated during this process $[5,6]$ and cooperates with FANCD2 in the ID (FANCI/FANCD2) complex [7,8]. The activated proteins of the ID complex subsequently colocalize with proteins of the distal FA pathway compartment (FANCD1/BRCA2, FANCN, and FANCJ) and with other DNA-repair proteins such as RAD51 at sites of DNA-damage. Cells having a defect in one of the proximal FA core complex genes are deficient in FANCD2/ FANCI monoubiquitination and FANCD2/FANCI nuclear focus formation. Similarly, cells having a defect in one of the distal FA pathway genes FANCD1 or FANCN are deficient in RAD51 focus formation [8-12]. Cells with a defect in one of the ID complex proteins lack the respective protein and are defective in monoubiquitination of the other. Thus, inactivation of the FA pathway can comprehensively be identified at the cellular level by assays detecting FANCD2 monoubiquitination and FANCD2/RAD51 focus formation.

FA pathway inactivation occurs sporadically in a variety of tumor types of non-FA patients, suggesting a role of the FA genes in tumor suppression or maintenance of genomic stability among the general population. Distal FA pathway inactivation via mutations in FANCD1 occurs in familial cases of breast (2-25\%) [13] and ovarian cancer (2-6\%) [14], in familial cases of pancreatic cancer (17\%) [15] and in sporadic cancers of various tumor entities [16-18]. In comparison, genetic inactivation of the proximal FA pathway appears to occur infrequently in tumors among the general population and has, in terms of GI cancers, yet only been reported in pancreatic cancer, where it was associated with rare mutations in FANCC or FANCG [19,20]. In addition, germline mutations of $F A N C C$ might contribute to the tumorigenesis or tumor progression of pancreatic cancer [20-22]. Finally, epigenetic inactivation of the proximal FA pathway via hypermethylation of $F A N C F$ has been reported in a variety of tumor entities [23-27], but its significance is not yet well understood $[28,29]$.

Unlike the setting in FA patients, FA pathway-deficient tumors arising in patients of the general population harbor the FA gene defect exclusively in the tumor cells, whereas stroma and all other non-malignant cells lack the defect, thus representing a tumor-specific, absolute biochemical difference [30]. As FA pathway-deficient cells are hypersensitive to ICL-agents and PARP inhibitors, FA pathway inactivation in tumors represents a promising target for rational, genotype-based anticancer therapy [31-38].

The prevalence of FA pathway defects has not yet been systematically investigated in GI cancer. We assessed proximal and distal FA pathway function in 48 cell lines derived from gastric, pancreatic, colorectal, hepatocellular and cholangiocellular carcinomas applying assays for FANCD2 monoubiquitination and FANCD2/RAD51 focus formation [39]. We newly identified a single cell line, $\mathrm{HuH}-7$, derived from a hepatocellular carcinoma (HCC), which exhibited a proximal FA pathway defect, ascribable to genetic $F A N C C$ inactivation. When compared to four other HCC cell lines, HuH-7 cells exhibited an increased sensitivity towards ICL-agents, which was reversible in these cells by genetic correction through FANCC overexpression. Our data represent the first evidence for genetic inactivation of the proximal FA pathway in $\mathrm{HCC}$ and further support the assumption that genetic inactivation of the proximal FA pathway is a rare event in solid tumors among the general population.

\section{Results}

\section{GI cancer cell line-screening identifies proximal FA} pathway-deficiency in HuH-7 cells

48 gastrointestinal cancer cell lines (18 colorectal, 15 pancreatic, 8 gastric, 5 hepatocellular and 2 cholangiocellular carcinomas) were screened for proximal and distal FA pathway inactivation using FANCD2 immunoblotting, FANCD2 and RAD51 nuclear focus formation (Fig. 1A, Table 1). Results on FA pathway inactivation in pancreatic cancer cell lines have been previously reported and were confirmed, including defective FANCD2 monoubiquitination due to inactivating mutations in FANCG and FANCC in Hs766T and PL11 [20,22], respectively, and defective RAD51 focus formation due to an inactivating FANCD1 mutation in Capan-1 [17]. Among all samples newly tested in the present study, we identified one cell line without detectable FANCD2 monoubiquitination, the HCC line HuH-7 (Fig. 1A). To stimulate previously undetectable FANCD2 monoubiquitination, $\mathrm{HuH}$ 7 cultures were pre-treated with mitomycin $\mathrm{C}(\mathrm{MMC})$ at $100 \mathrm{nM}$ for $24 \mathrm{~h}$. Despite such challenge, $\mathrm{HuH}-7$ did not display any trace of monoubiquitinated FANCD2. RKO cells and derived clones harboring an engineered disruption of FANCG or FANCC were used as controls [36] (Fig. 1B). Likewise, no FANCD2 focus formation was observed in HuH-7 after treatment with irradiation (IR) at 15 Gy 6 $\mathrm{h}$ prior to workup (Fig. 2A). In contrast, RAD51 focus formation was readily detectable (Fig. 2B), confirming a proximal FA pathway defect, whereas distal FA/BRCA pathway function remained undisturbed.

\section{Gene complementation studies reveal defective FANCC function in HuH-7 cells}

To identify the FA gene responsible for proximal FA pathway inactivation, HuH-7 cells were transduced with retroviral constructs containing full-length cDNAs of FANCA, FANCB, FANCC, FANCE, FANCF, FANCG or 
Table 1: FANCD2- and RAD51-nuclear focus formation in $48 \mathrm{GI}$ cancer cell lines

\begin{tabular}{|c|c|c|c|c|c|c|c|}
\hline Cell line & Cancer type & FANCD2 & RAD51 & Cell line & Cancer type & FANCD2 & RAD51 \\
\hline AGS & gastric & + & + & L3.6pl & pancreatic & + & + \\
\hline AsPC-1 & pancreatic & + & + & LoVo & colorectal & + & + \\
\hline AZ-521 & gastric & + & + & LS1034 & colorectal & + & + \\
\hline $\mathrm{BxPC}-3$ & pancreatic & + & + & LS513 & colorectal & + & + \\
\hline Caco-2 & colorectal & + & + & MIA PaCa-2 & pancreatic & + & + \\
\hline Capan-1 & pancreatic & + & - & MKN 45 & gastric & + & + \\
\hline Capan-2 & pancreatic & + & + & MKN 7 & gastric & + & + \\
\hline CFPAC- 1 & pancreatic & + & + & NCl-N87 & gastric & + & + \\
\hline Chang & hepatocellular & + & + & PANC-1 & pancreatic & + & + \\
\hline CoGa 12 & colorectal & + & + & PL11 & pancreatic & - & + \\
\hline CoGa 5 & colorectal & + & + & PL3 & pancreatic & + & + \\
\hline CoGa 5L & colorectal & + & + & PL45 & pancreatic & + & + \\
\hline Colo 320 & colorectal & + & + & PL5 & pancreatic & + & + \\
\hline DLD-1 & colorectal & + & + & PL8 & pancreatic & + & + \\
\hline EGl-1 & cholangiocellular & + & + & PLCPRF5 & hepatocellular & + & + \\
\hline $\mathrm{HCA}-7$ & colorectal & + & + & SNU-1 & gastric & + & + \\
\hline НCT 116 & colorectal & + & + & SNU-5 & gastric & + & + \\
\hline Нер3В & hepatocellular & + & + & SU.86.86 & pancreatic & + & + \\
\hline HepG2 & hepatocellular & + & + & SW48 & colorectal & + & + \\
\hline Hs766T & pancreatic & - & + & SW480 & colorectal & + & + \\
\hline HT-29 & colorectal & + & + & SW620 & colorectal & + & + \\
\hline HuH-7 & hepatocellular & - & + & SW948 & colorectal & + & + \\
\hline Isreco 1 & colorectal & + & + & TFK-1 & $\begin{array}{c}\text { cholangiocellu } \\
\text { lar }\end{array}$ & + & + \\
\hline KATO III & gastric & + & + & WiDr & colorectal & + & + \\
\hline
\end{tabular}

(+) detectable or (-) no detectable nuclear focus formation of FANCD2 or RAD51, respectively, in the indicated cell lines, $6 \mathrm{~h}$ after treatment with IR at 15 Gy. FA pathway-deficient cell lines are depicted in bold.

FANCL. FANCD2 monoubiquitination was assessed following exposure of the transduced cultures to MMC. Restoration of FANCD2 monoubiquitination was observed only after complementation of $\mathrm{HuH}-7$ cells with the FANCC gene construct, whereas all other constructs had no discernible effect (Fig. 3A). Consequently, exogenous FANCC protein expression was confirmed in FANCC-transduced HuH-7 cultures (Fig. 3B). To validate functional FA pathway restoration upon transduction of $F A N C C$-cDNA, the cell cycle profiles of the transduced cells were analyzed $48 \mathrm{~h}$ after treatment with $\mathrm{MMC}$. The pronounced G2 arrest, observed in non-FANCC-complemented HuH-7 cells was restored to normal specifically after transduction with $F A N C C$, but not after transduction with any of the other FA or control constructs (Fig. 3C).
HuH-7 cells harbor a homozygous inactivating nonsense FANCC mutation in exon 6

Direct genomic sequencing of the coding exons and adjacent intron portions of FANCC in $\mathrm{HuH}-7$ revealed a homo- or hemizygous inactivating nonsense mutation c.553C > T, p.R185X in coding exon 6 (Fig. 3D). No other sequence changes were identified.

\section{Aberrant splicing leads to a truncated FANCC mRNA lacking exon 6 in $\mathrm{HuH}-7$ cells}

Using reverse-transcription PCR (RT-PCR) with primers flanking a region that includes exon 6 , we identified an additional truncated FANCC gene transcript in $\mathrm{HuH}-7$ cells, which was not detectable in four HCC control cell lines Chang, Hep3B, HepG2 and PLCPRF5 (Fig. 3E). Upon gel-separation of the two RT-PCR products amplified from $\mathrm{HuH}-7$ cDNA, direct sequencing confirmed 


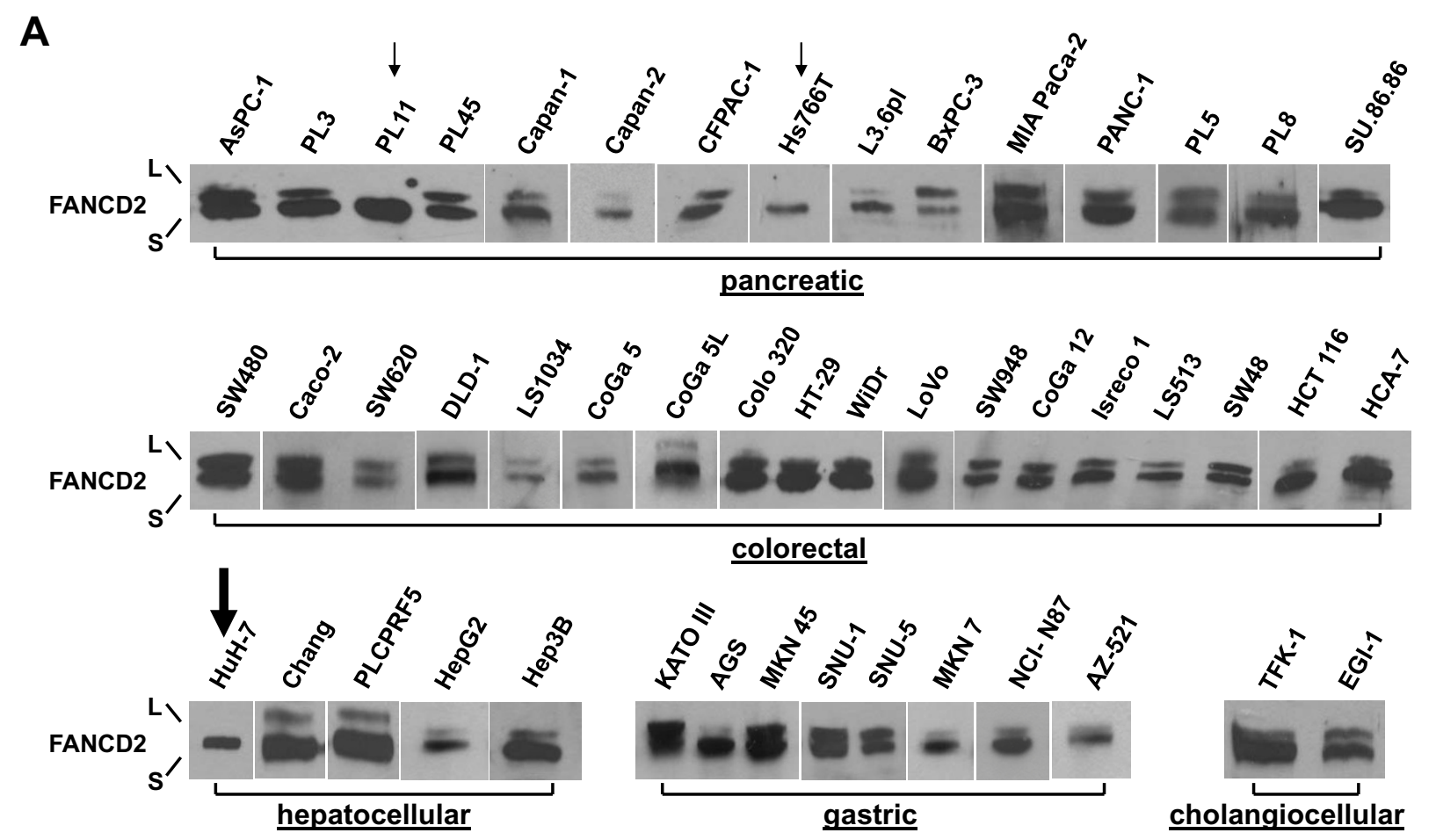

B

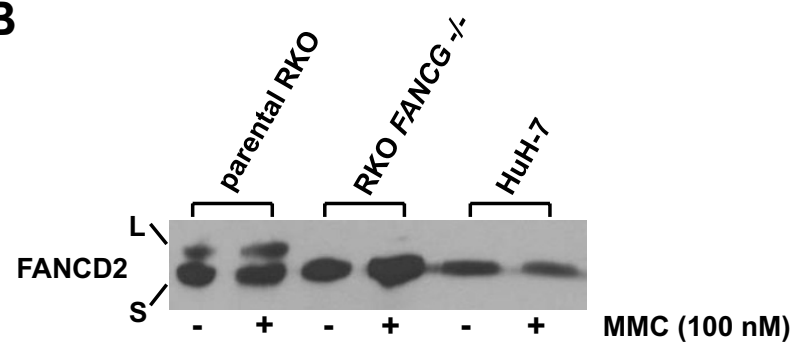

Figure 1 Detection of monoubiquitinated (L) and non-monoubiquitinated (S) FANCD2 protein to assess proximal FA pathway status in GI cell lines. (A) Immunoblotting to assess FANCD2 monoubiquitination in 48 tumor cell lines of pancreatic, colorectal, hepatocellular, gastric and cholangiocellular origin. Pancreatic cell lines were described previously, including the FA pathway-deficient cell lines Hs766T and PL11 (small arrows), and served as controls. The HCC cell line HuH-7 (big arrow) lacked spontaneous FANCD2 monoubiquitination. (B) FANCD2 immunoblotting of RKO cells (positive control), derived RKO FANCG -/-cells (negative control) and HuH-7 cells upon treatment with MMC at $100 \mathrm{nM}$ for $24 \mathrm{~h}$ to stimulate potential previously undetectable FANCD2 monoubiquitination.

that the correctly sized band represented the reference FANCC sequence except for the described c.553C $>\mathrm{T}$ nonsense mutation, while the smaller band represented the reference $F A N C C$ sequence lacking exon 6, leading to a direct exon $5 / 7$ junction (Fig. 3F).

\section{HuH-7 cells are hypersensitive towards ICL-agents as compared to other HCC lines}

Five HCC cell lines (Chang, Hep3B, HepG2, HuH-7 and PLCPRF5) were treated either with common ICL-agents (MMC, cisplatin and melphalan) or with common nonICL chemotherapeutics (5-fluorouracil (5-FU), etoposide and doxorubicin). The sensitivity towards ICL-agents was clearly dissimilar between the FA pathway-proficient cell line panel and FANCC-deficient $\mathrm{HuH}-7$ cells, with the latter displaying a distinct hypersensitivity (inhibitory concentration 50\% (IC50) ratios [40] ranging between 3.4 to 18.6 as compared to the other HCC lines) (Fig. 4A, upper panel). In contrast, treatment with non-ICL chemotherapeutics did not distinguish $\mathrm{HuH}-7$ as being most sensitive (Fig. 4A, lower panel). The most consistent difference in ICL-agent sensitivity between the FA-pathway proficient $\mathrm{HCC}$ cell lines and FANCC-deficient $\mathrm{HuH}-7$ cells was observed using melphalan. This agent has previously been described to have the strongest effect among 8 ICL-agents tested in an isogenic FA cancer cell model 
A
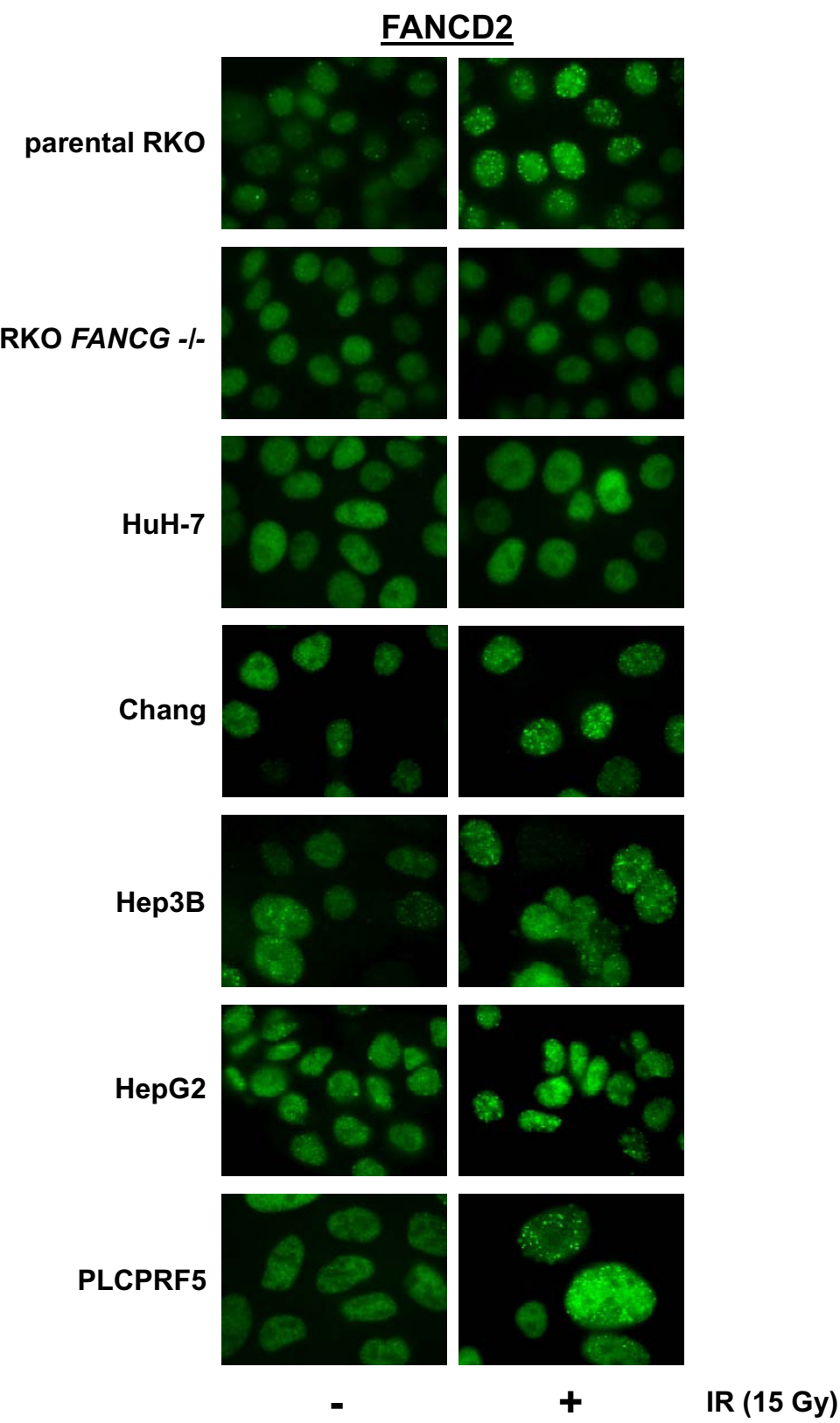

B

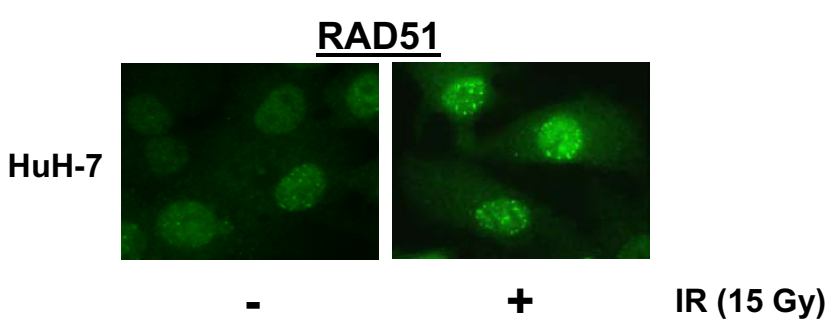

Figure 2 FANCD2 and RAD51 nuclear focus formation to assess proximal and distal FA pathway function. (A) FANCD2 nuclear focus formation in RKO cells (positive control), derived RKO FANCG -/- cells (negative control), and a panel of five HCC cell lines including HuH-7, either treated with IR at 15 Gy for 6 h or left untreated. HuH-7 and RKO FANCG -/- cells lacked FANCD2 focus formation. (B) RAD51 nuclear focus formation in HuH-7 cells either treated with IR at 15 Gy for 6 h or left untreated. 
A

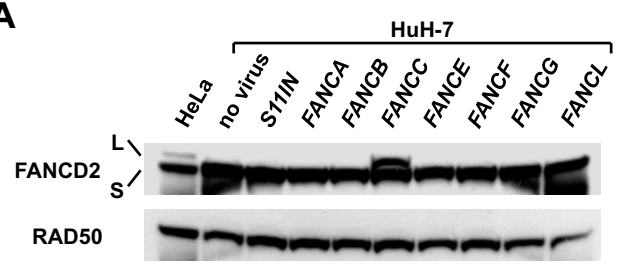

B

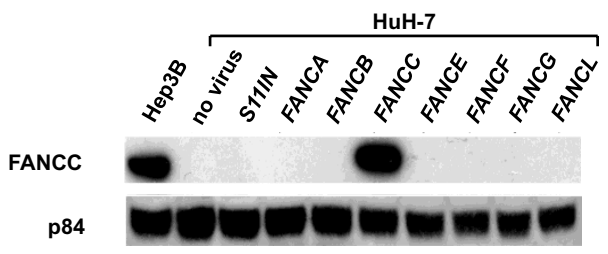

D

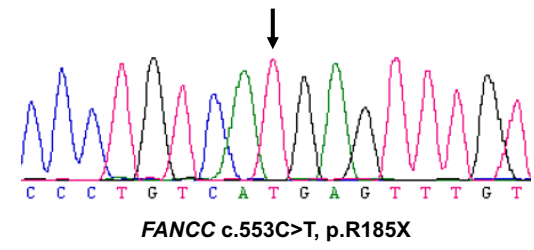

inactivating nonsense mutation
C

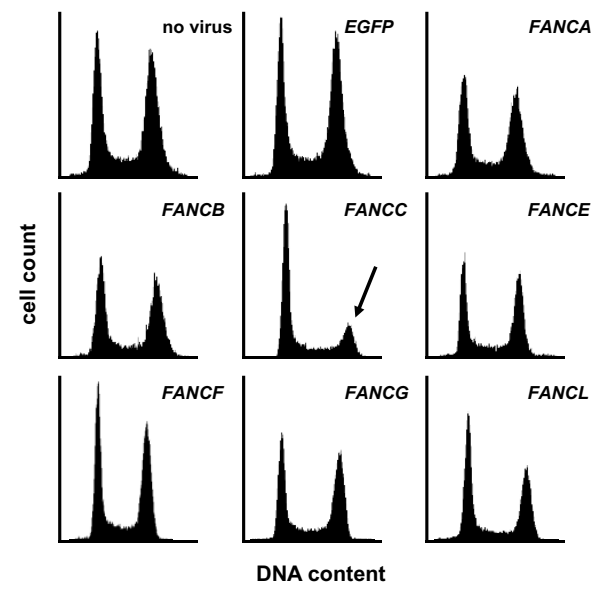

$\mathbf{E}$

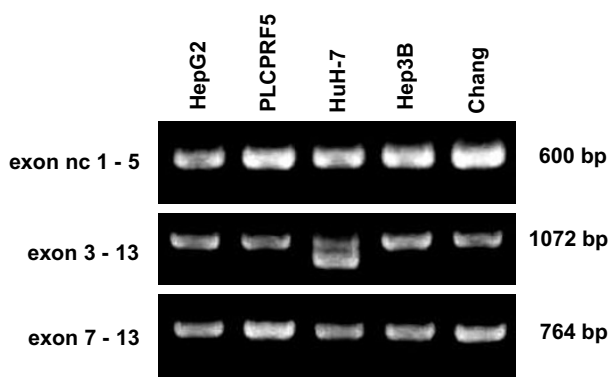

$\mathbf{F}$

correct-size product

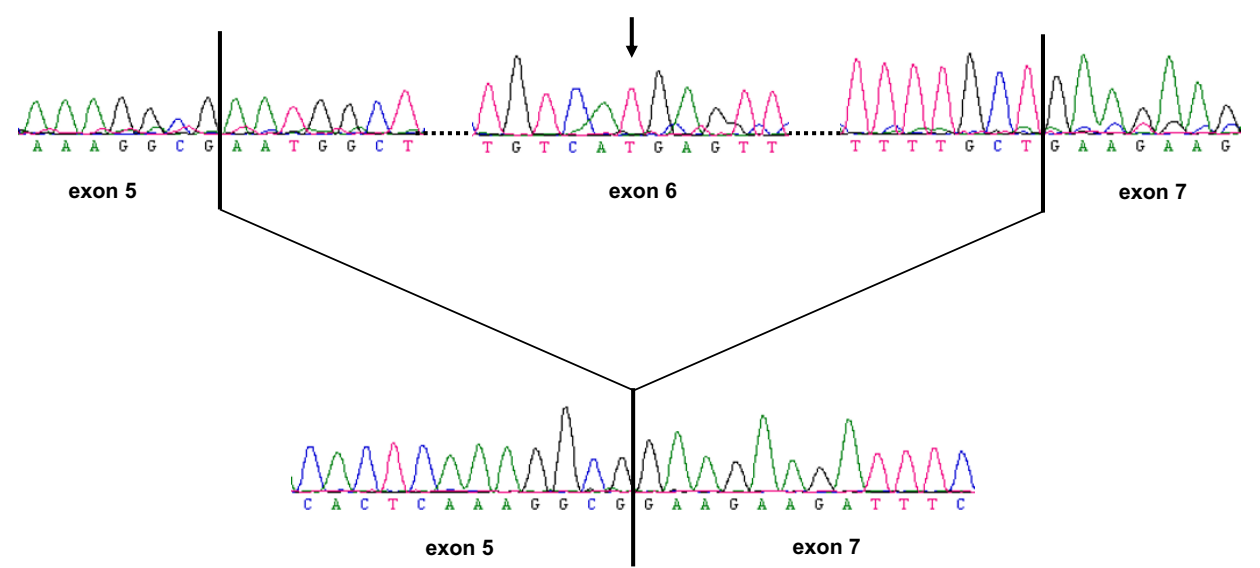

Figure 3 Gene complementation studies identifying an inactivating FANCC nonsense mutation in HuH-7. (A) FANCD2 monoubiquitination in FA pathway-proficient control HeLa cells and $\mathrm{HuH}-7$ cells transduced with the indicated FA or control CDNA constructs. All cultures were exposed to MMC at $150 \mathrm{nM}$ for $15 \mathrm{~h}$. RAD50 served as loading control. Only transduction with FANCC restored FANCD2 monoubiquitination in HuH-7 cells. (B) FANCC immunoblotting using the indicated cell lysates. The nuclear protein p84 served as loading control. Only HuH-7 cells transduced with FANCC and FA pathway-proficient Hep3B control cells displayed FANCC protein. (C) Cell cycle distributions of HuH-7 cells transduced with the indicated FA or control cDNA constructs. All cultures were exposed to MMC at $33 \mathrm{nM}$ for $15 \mathrm{~h}$. Only transduction with FANCC abrogated the pronounced G2 cell cycle arrest upon MMC in HuH-7 cells. (D) Chromatogram of the homo- or hemizygous FANCC mutation (arrow) identified in HuH-7 cells. (E) RT-PCR using three different primer pairs amplifying a region from FANCC non-coding exon 1 to coding exon 5, or from coding exons 3 to 13, or from coding exons 7 to 13, respectively, using cDNA from five HCC cell lines. Only HuH-7 cells exhibited aberrant mRNA splicing lacking exon 6. (F) Direct sequencing of the two distinct RT-PCR products confirmed that the product having the correct size represented the reference FANCC sequence except for the c.553C > T mutation, whereas the shorter product lacked exon 6, exhibiting a direct exon 5/7 junction. 
[36]. Cell cycle distributions of the five HCC cell lines, analyzed upon treatment with MMC for $48 \mathrm{~h}$, revealed a pronounced G2 arrest (defined here by a fraction of $>40 \%$ of cells in G2) [36] at low MMC concentrations (25 nM) only in $\mathrm{HuH}-7$ cells (Fig. 4B), whereas a similar G2 arrest was achieved in a dose-dependent manner in all HCC cell lines except PLCPRF5 at higher MMC concentrations (50 to $100 \mathrm{nM})$ (Fig. 4C).

\section{ICL-hypersensitivity of HuH-7 cells is abrogated upon exogenous FANCC expression}

HuH-7 cells were stably transduced using retroviral constructs containing either full length $F A N C C$-cDNA (HuH-7/FANCC), tagged with recombinant influenza virus hemagglutinin (HA-tag), or empty vector (HuH-7/ ev). Consecutively, exogenous $F A N C C$ expression was confirmed (Fig. 5A). HuH-7/FANCC cells, but not parental HuH-7 or HuH-7/ev control cells, displayed restored proximal FA-pathway function as demonstrated by constitutive and MMC-inducible [41] FANCD2 monoubiquitination (Fig. 5B) as well as proficiency in FANCD2 nuclear focus formation (Fig. 5C). Most importantly, sensitivity towards ICL-agents was significantly reduced in $\mathrm{HuH}-7 / F A N C C$ cells as compared to parental $\mathrm{HuH}-7$ and HuH-7/ev control cells (Fig. 5D, upper panel), whereas sensitivity towards non-ICL-chemotherapeutics remained virtually unchanged (Fig. 5D, lower panel).

\section{No evidence for inactivation of FANCC, FANCG or FANCF in $18 \mathrm{HCC}$ tissue specimens}

To assess the prevalence of proximal FA pathway inactivation in HCC, 18 surgical HCC tissue specimens were analyzed for inactivation of FANCC, FANCF or FANCG through screening for genetic mutations, epigenetic silencing through CpG hypermethylation or lack of mRNA-expression. On the genetic level, direct sequencing of the complete coding sequences of FANCC, FANCF and FANCG in $18 \mathrm{HCC}$ samples identified a single not previously reported, heterozygous, synonymous $F A N C C$ sequence variant (c.813G > A) and two heterozygous, non-synonymous FANCG variants (c.20C > T, p.S7F; c.643C > A, p.Q215K) (Fig. 6A). No other sequence variants, especially no inactivating point mutations, small deletions, insertions, large intragenic deletions or complete homozygous gene deletions, were found. On the epigenetic level, HpaII-restriction assays yielded no evidence for FANCC-, FANCF- or FANCG-silencing through CpG hypermethylation (Fig. 6B) and consistently, FANCC-, FANCF- and FANCG-mRNA was detectable in all 18 HCC samples (Fig. 6C).

\section{Discussion}

We report here the identification and functional characterization of an inactivating nonsense FANCC mutation in the HCC cell line HuH-7. This cell line was established from a well-differentiated $\mathrm{HCC}$ of a 57 year-old Japanese male patient [42], displays an aneuploid phenotype with an average number of 60 chromosomes, and is negative for HBV and HCV $[43,44]$. To our knowledge, this is the first evidence of genetic inactivation of the proximal FA pathway in a GI tumor entity other than pancreatic cancer.

The identified FANCC nonsense mutation c.553C > T, p.R185X in HuH-7 represents a known FA mutation, first described by Gibson et al. [45]. Interestingly, non-splice site nonsense mutations can cause exon-skipping through aberrant splicing [46], and accordingly, the c.553C $>\mathrm{T}$ mutation has been reported to cause partial transcriptional skipping of exon 6 of FANCC in an FA patient [45], a mechanism confirmed for $\mathrm{HuH}-7$ in our study.

Unfortunately, no matched non-malignant tissue is available for $\mathrm{HuH}-7$, precluding definitive genomic copy number analyses in regard to whether the identified FANCC mutation represents a homo- or hemizygous mutation in this cell line. However, according to copy number analyses by the Sanger Institute (Cambridge, UK) using high-density single nucleotide polymorphism (SNP) arrays (SNP 6.0) [47], HuH-7 harbors three nearly identical copies of the chromosomal arm 9q, where FANCC is located at $9 \mathrm{q} 22.3$, as evidenced by virtually exclusive homozygosity of all SNPs assessed on 9q. According to proposed evaluation models for the identification of $\mathrm{LOH}$ events where no matching normal tissue is available, these data are strongly suggestive (although not definitely evidentiary) of allelic loss of one copy of chromosome 9q including the non-mutated FANCC allele in the original tumor (or its precursor cells), followed by repeated duplication of the remaining chromosome $9 \mathrm{q}$, including the mutated FANCC allele, later on [48-50]. Typical recurrent numerical chromosomal aberrations in HCC include losses on 1p, 4q, 8p, 13q, 16q, and 17p and gains on 1q, 8q, 16p and 20q [51]. Although chromosome 9 is rarely clonally altered on the cytogenetic level in $\mathrm{HCC}, \mathrm{LOH}$ has been reported for several regions on chromosome 9 including the loci of the FANCC (9q22.3) and the FANCG (9p13) genes [52].

FA pathway defects in tumors require bi-allelic inactivation of one of at least $13 \mathrm{FA}$ genes. On the one hand, these bi-allelic mutations could both be inherited, as applies to tumors occurring in FA-patients. On the other hand, mono-allelic germline mutations of distal FA pathway genes, such as FANCD1, FANCN or FANCJ, confer low to medium penetrance susceptibility for breast/ovarian cancer $[12,13,53]$ and, as applies to $F A N C D 1$ and $F A N C N$, also for pancreatic cancer [15,54-57]. In addition, inherited mono-allelic mutations of proximal FA pathway genes have been associated with the predisposi- 

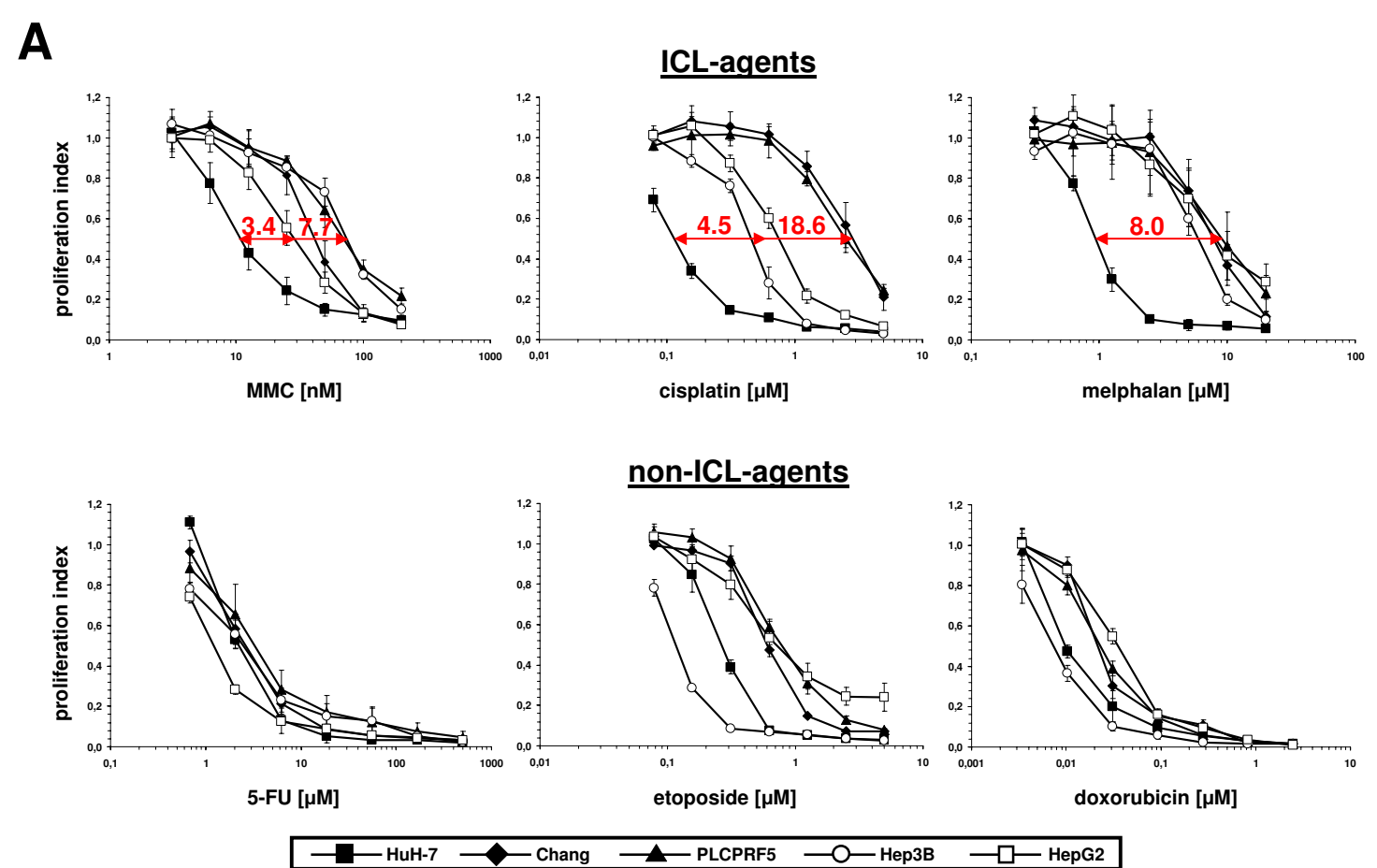

B

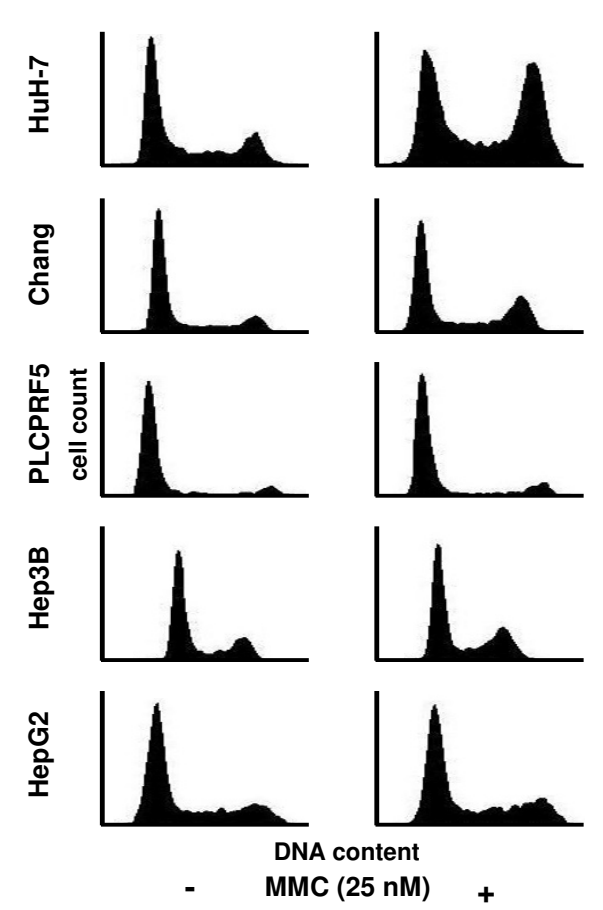

C
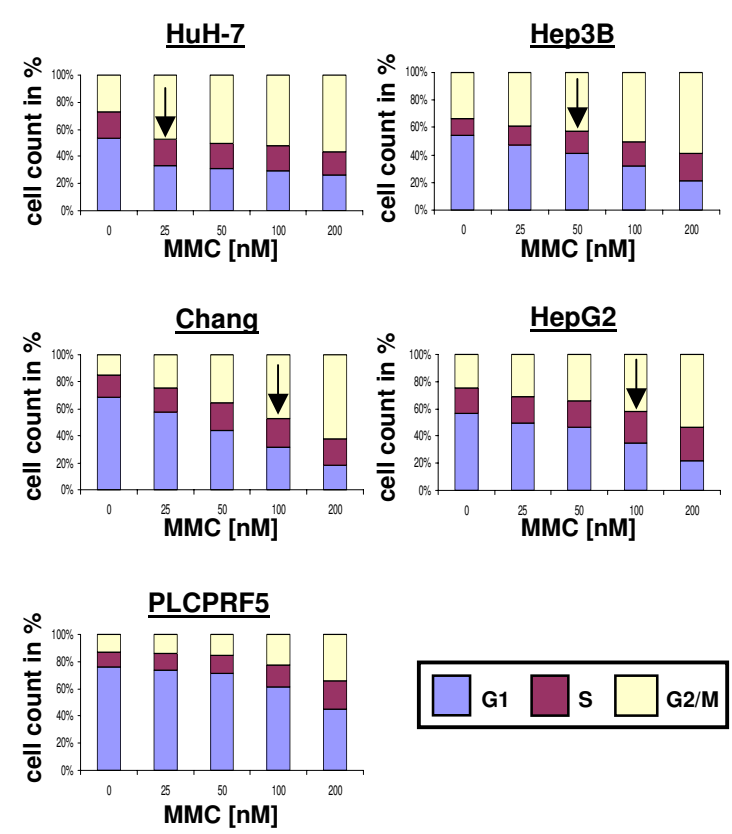

Figure 4 Hypersensitivity of HuH-7 cells specifically towards ICL-agents. (A) Cell proliferation assays to compare the sensitivity of five HCC cell lines towards ICL- and non-ICL-chemotherapeutic agents. $\mathrm{HuH}-7$ cells were hypersensitive towards treatment with any of three ICL-agents as compared to four FA pathway-proficient HCC lines (upper panel: MMC, cisplatin, melphalan), with IC50 ratios ranging from 3.4- to 18.6-fold (arrows, indicated in red), but not towards any of three non-ICL-agents (lower panel: 5-FU, doxorubicin, etoposide). Error bars represent SEM of three independent experiments. (B) Flow cytometric cell cycle profiles of five HCC cell lines $48 \mathrm{~h}$ after treatment with MMC at the indicated concentrations. A pronounced G2 arrest (defined here as a cell fraction of $>40 \%$ in G2 [36]) at low-dose MMC (25 nM) was observed only in HuH-7 cells. (C) Graphic representation of the cell cycle distributions from a representative experiment displaying the fraction of cells in G1, S or G2 at the indicated MMC concentrations for the indicated HCC cell lines. Arrows indicate the lowest dose at which a G2 arrest of more than $40 \%$ of the cells was observed. 
A

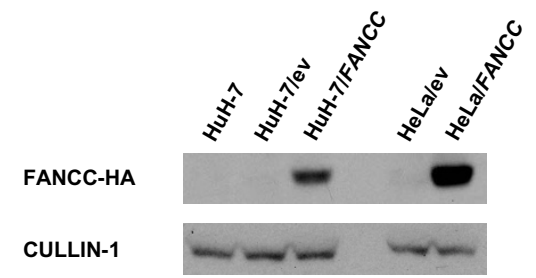

B

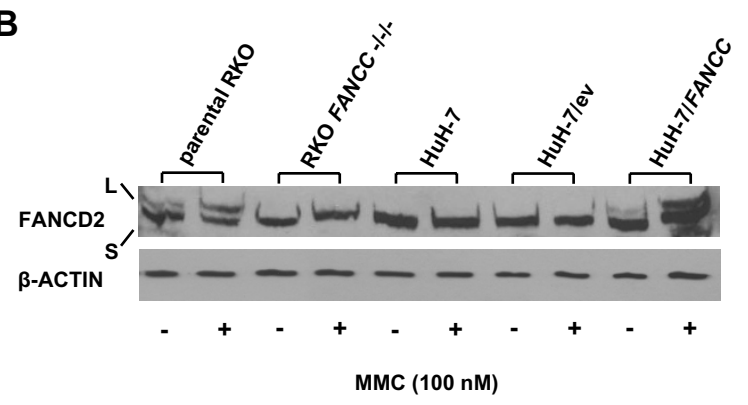

C

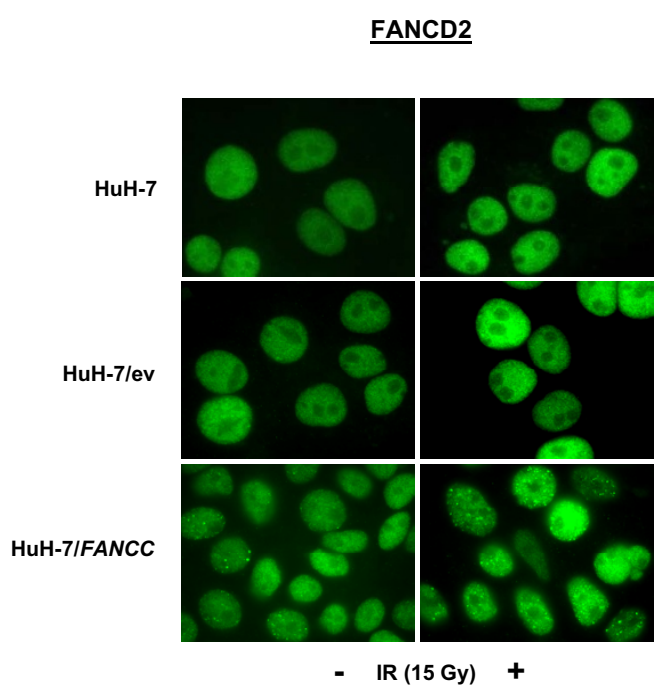

D

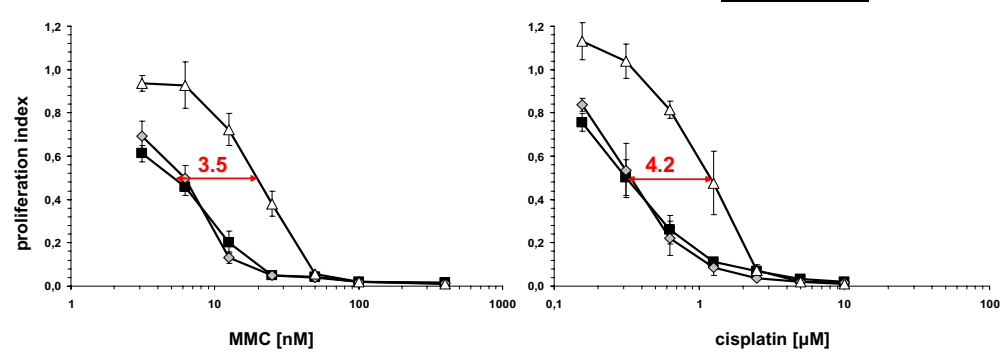

$\underline{\text { non-ICL-agents }}$

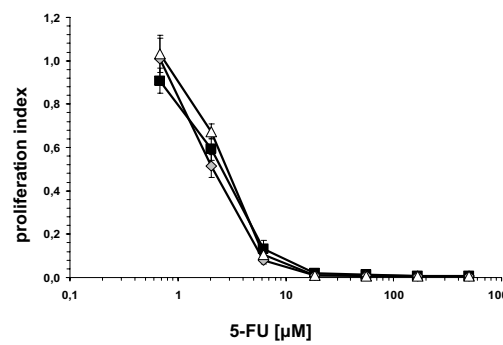

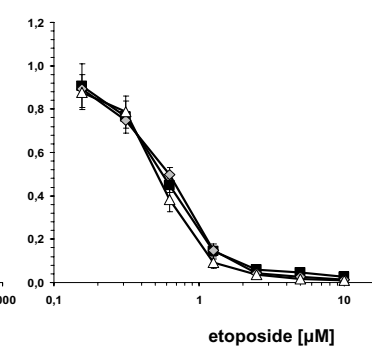

- HuH-7 $\neg$-HuH-7/ev $\triangle$ HuH-7IFANCC

Figure 5 Abrogation of the ICL-hypersensitivity phenotype in HuH-7 through exogenous FANCC expression. (A) Immunoblotting for the detection of FANCC-HA in parental HuH-7 cells (HuH-7) and HuH-7-derived clones retrovirally transduced with either empty vector-pMSCV (HuH-7/ev) or with pMSCV-FANCC (HuH-7/FANCC). HeLa cells transduced with pMSCV-FANCC were used as controls. CULLIN-1 served as loading control. FANCCHA was detectable only in HuH-7/FANCC and control HeLa/FANCC cells. (B) FANCD2 monoubiquitination in parental HuH-7, HuH-7/ev and HuH-7/ FANCC cells, respectively, either treated with MMC at $100 \mathrm{nM}$ for $24 \mathrm{~h}$ or left untreated. RKO cells and derived RKO FANCC-/-/- cells were used as controls. $\beta$-ACTIN served as loading control. Monoubiquitinated FANCD2 was detectable only in HuH-7/FANCC and parental RKO control cells and was inducible upon MMC-treatment, confirming correction of proximal FA pathway function through exogenous FANCC expression in HuH-7. (C) FANCD2 nuclear focus formation in parental $\mathrm{HuH}-7, \mathrm{HuH}-7 / \mathrm{ev}$ and $\mathrm{HuH}-7 /$ FANCC cells either treated with IR at $15 \mathrm{~Gy}$ for $6 \mathrm{~h}$ or left untreated. FANCD2 focus formation was detectable only in HuH-7/FANCC cells. (D) Cell proliferation assays to compare the sensitivity of parental HuH-7, HuH-7/ev and HuH-7/ FANCC cells towards ICL- and non-ICL-chemotherapeutic agents. HuH-7/FANCC cells were less sensitive towards treatment with ICL-agents than parental and HuH-7/ev control cells (upper panel: MMC, cisplatin, melphalan), with IC50 ratios ranging from 3.4- to 4.2-fold (arrows, indicated in red), whereas sensitivity towards non-ICL-agents (lower panel: 5-FU, doxorubicin, etoposide) remained virtually unchanged. Error bars represent SEM of three independent experiments. 


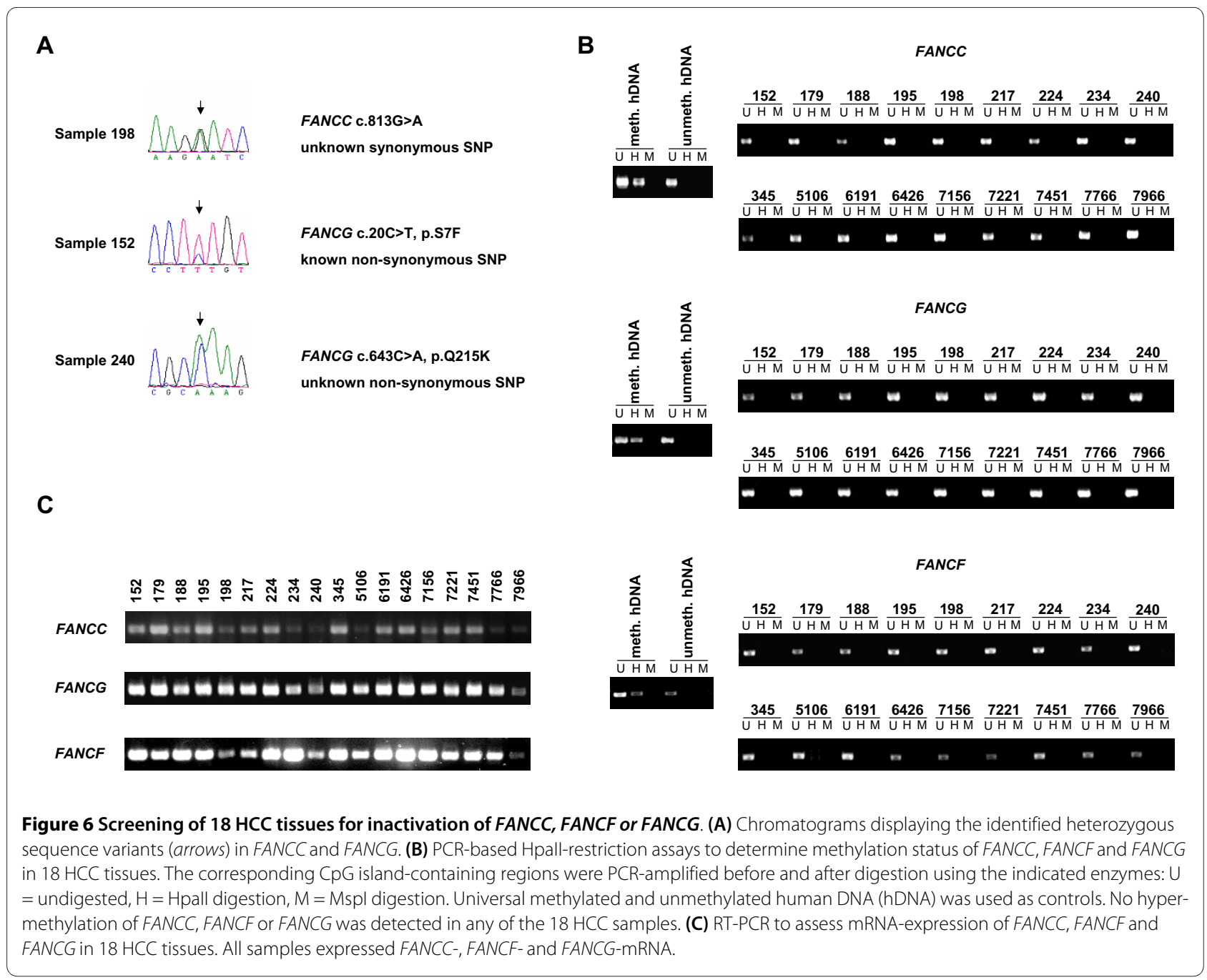

tion for or the accelerated development of certain tumors $[21,54,55,58]$. In particular, germline mutations of FANCC have been described in pancreatic cancer, associated with $\mathrm{LOH}$ in the tumor $[21,22]$. However, germline and somatic changes in FANCC and FANCG may have comparatively low penetrance for pancreatic cancer [55], which is supported by studies investigating germline mutations of upstream FA pathway genes in sporadic, yet FA-typical tumors among the general population [59]. Nevertheless, as the FANCC mutation in HuH-7 reported in our study represents an established FA mutation and was therefore most likely present in the germline of the patient in mono-allelic form, our data might indicate an increased risk for the development of HCC in individuals of the general population harboring this or other FANCC mutations.

The occurrence of an FA-associated FANCC mutation in HCC could also denote a tissue-specific susceptibility for the development of HCC in FA patients; The majority of solid malignancies seen in FA patients consists of head and neck or gynaecologic carcinomas (5.3\%), as reported in a large meta-analysis of 1300 cases [60], but also $2.8 \%$ of all FA patients developed liver tumors. These tumors manifested at a significantly younger age than other solid malignancies (median age: 13 years for liver tumors as compared to 26 years for other solid malignancies). In fact, the cumulative probability of liver tumors in FA patients has been estimated to be $46 \%$ by age 50 [60]. However, the significance of these data regarding a potential liver-specific cancer susceptibility of FA patients is complicated by the observation that many liver tumors do not proceed to malignancy during the life span of FA patients $[60,61]$. In addition, there appears to be a strong association between androgen therapy, which is frequently used for the treatment of bone marrow failure in FA, and the occurrence of liver tumors [60-63]. Nevertheless, $\mathrm{HCC}$ represented the majority (58\%) of tumors of $36 \mathrm{FA}$ patients with androgen-related liver tumors in one study [61]. Thus, the association of FA with HCC could be attributable both to the primary tumorigenic effects of 
FA pathway inactivation in hepatocytes, as well as to potential secondary, amplifying or accelerating effects of androgen therapy in FA patients.

We demonstrated that HCC cells having an inactivated FA pathway display the classic cellular FA phenotype, including a specific hypersensitivity towards ICL-agents, illustrated in HuH-7 by a pronounced cell cycle arrest in G2 upon treatment with MMC at low concentrations and a strongly decreased proliferation rate as compared to a panel of non-isogenic HCC lines. Importantly, this ICLhypersensitivity phenotype was reversed using an isogenic HuH-7 model of exogenous FANCC expression, confirming that ICL-hypersensitivity in these cells was attributable specifically to inactivation of FANCC. Of note however, IC50-ratios between $F A N C C$-deficient and FANCC-proficient cells were partly smaller in the isogenic model than could have been expected from our results using the non-isogenic model. This observation could be attributable to FA pathway-independent ICLsensitivity differences among the non-isogenic HCC cell lines, but could also provide further support for our previous hypothesis that constitutive exogenous FANCC over-expression does not completely substitute for physiologically regulated, endogenous FANCC expression $[37,38]$.

It is well established that systemic chemotherapy lacks effectiveness in unselected HCC patients [64,65] and HCC are therefore considered largely chemoresistant, at least partially explaining the poor prognosis of this tumor entity [66]. Accordingly, guidelines are currently lacking also regarding the choice of chemotherapeutic agent to use in transarterial chemoembolization (TACE), one of the major treatment modalities for non-surgical patients at advanced HCC stages [67]. Our data indicate that nonFA patients having a FA-deficient HCC might predictably benefit from treatment using ICL-agents. Consequently, assessment of FA pathway function in HCC could facilitate individualized therapeutic approaches, using genotype-based patient stratification in regard to both systemic chemotherapy and TACE.

To get an estimate of the prevalence of FANCC inactivation in $\mathrm{HCC}$, we sequenced cDNA derived from 18 surgical HCC tissue specimens to screen for genetic FANCC inactivation. We further screened these samples for hypermethylation of the FANCC promoter region and for lack of FANCC mRNA expression, as epigenetic FANCC inactivation has previously been reported in acute leukaemia and breast cancer [68,69]. Additionally, we included FANCG and FANCF in these analyses, as FANCG represents another proximal FA gene that has been described to be mutated in GI cancer, specifically in pancreatic cancer [20,22], while FANCF has been reported to be epigenetically inactivated in various tumor types [23-25,27]. On the genetic level, we found no further inactivating alterations, especially no evidence for complete homozygous gene deletions, inactivating point mutations, small deletions or insertions, in FANCC, FANCG or FANCF, respectively. The detected FANCG variant c.20C > T, p.S7F has been reported in an FA patient of the complementation group $\mathrm{G}$ in addition to pathogenic FANCG mutations [70]. There is no information available on the nature of the c.643C > A, p.Q215K variant in FANCG. However, $\mathrm{LOH}$ or a second sequence variant was not detected in that tumor either. Additionally, since only two to three overlapping PCR reactions were used to amplify the complete coding sequences of FANCC, FANCG and FANCF, respectively, most potential large intragenic deletions would have been detected. However, this mechanism of proximal FA gene inactivation occurs almost exclusively in FANCA, whereas it appears to be extremely rare in $F A N C C$ and has not at all been described in FANCG [20,71-73]. On the epigenetic level, we found no evidence for hypermethylation of FANCC, FANCG or FANCF in any of the 18 samples. Consistently, FANCC, FANCG and FANCF were expressed in all samples on the mRNA level.

Our negative screening results for proximal FA pathway inactivation in $\mathrm{HCC}$ were not unexpected, as a hypothetical high prevalence should have become evident earlier during clinical trials - manifesting as a selective chemosensitivity of the majority of HCC towards ICL-agents. Nevertheless, the lack of FA mutations in 18 HCC does not rule out rare occurrences of proximal FA pathway inactivation in HCC and is consistent with previous reports on the low prevalence of proximal FA pathway inactivation in various tumor entities among the general population [20-22,26,29,68]. Future studies applying a higher sample number are required to definitely determine the prevalence of FA pathway inactivation in HCC.

\section{Conclusions}

In summary, we identified a $\mathrm{HCC}$ cell line harboring an inactivating mutation of the FANCC gene, specifically causing proximal FA pathway inactivation and the classic cellular ICL-hypersensitivity phenotype. Assessment of FA pathway function in HCC could thus represent a novel approach to identify small subgroups of HCC patients expected to predictably benefit from individualized treatment protocols using ICL-agents. However, as proximal FA pathway inactivation occurs at low frequency in HCC and other tumors among the general population, the development of rapid, economic and clinically applicable screening tests for proximal FA pathway inactivation, particularly in primary tumor tissues, remains an indispensable requirement to facilitate future clinical studies [38]. 


\section{Materials and methods}

Cell lines, culture conditions and HCC tissue samples

Cell lines PL3, PL5, PL8, PL11 and PL45 were kindly provided by S.E. Kern (Johns Hopkins University, Baltimore, Maryland). Cell lines AZ-521, CoGa-5, CoGa-5L, Coga12, HCA-7, Isreco 1, MKN7, MKN45, NCl-N87 and L3.6pl were kindly donated by C.J. Bruns, M. Gerhard, F.T. Kolligs and M. Ogris (Technical University and Ludwig-Maximilians-University, Munich, Germany). The remaining cell lines were purchased from the European Collection of Cell Cultures (Sigma-Aldrich, Munich, Germany) or the American Type Culture Collection (LGC Standards, Wesel, Germany). RKO cells harboring an engineered disruption of the FANCG or FANCC gene have been described [36]. Cells were grown in DMEM supplemented with $10 \%$ fetal calf serum, L-glutamine and penicillin/streptomycin (PAA, Cölbe, Germany). The 18 HCC tissue samples were a kind gift of the Human Tissue and Cell Research-Trust (HTCR, Regensburg, Germany) and originated from HCCs that where surgically removed at the Ludwig-Maximilians-University (Munich, Germany).

\section{Immunoblotting}

Cells were treated with MMC (Sigma) at $100 \mathrm{nM}$ for $24 \mathrm{~h}$ or left untreated. Consecutively, cells were lysed and protein extracts boiled and loaded on $6 \%$ polyacrylamide gels. After electrophoresis, proteins were transferred to PVDF membranes, which were blocked for $1 \mathrm{~h}$ in TBSTriton $\mathrm{X}-100 / 2 \%$ milk before the primary antibody was applied overnight at $4^{\circ} \mathrm{C}(1: 1000$; anti-FANCD2 H-300, Santa Cruz Biotechnology, Heidelberg, Germany; antiFANCC ab5065, Abcam, Cambridge, UK). HA-tagged FANCC was detected using an anti-HA antibody (1:1000; 12CA5, Santa Cruz). Antibodies directed against antiRAD50 (1:5000; 13B3, GeneTex, San Antonio, TX), antip84 (1:1000; ab487, Abcam), anti-CUL1 (1:1000; 2H4C9, Invitrogen, Karlsruhe, Germany) or anti- $\beta$-ACTIN (1:10.000; AC-15, Sigma) served as loading controls. The membranes were washed and stained with anti-rabbit or anti-mouse HRP-conjugated antibodies (1:2000 to 1:10.000; GE Healthcare, Freiburg, Germany). Enhanced chemo-luminescence was elicited using SuperSignal West Pico substrate (Thermo Scientific, Schwerte, Germany) according to the manufacturer's instructions.

\section{Nuclear focus formation assays}

Experiments were performed as described before [74]. In brief, cells were grown on coverslips until $\sim 80 \%$ confluency and were exposed to ionizing $\gamma$-radiation (IR) at 15 Gy using a cesium-137 irradiator. After incubation for 6 $\mathrm{h}$, the cells were fixed using $3.7 \%$ formaldehyde and $-20^{\circ} \mathrm{C}$ methanol. The cells were permeabilized using Triton X100 and incubated in blocking buffer (PBS $+2 \%$ bovine serum albumin $+0.5 \%$ Triton $\mathrm{X}-100$ ) for $30 \mathrm{~min}$. Consecutively, the cells were labelled using antibodies against FANCD2 (FI-17) or RAD51 (H-92) (Santa Cruz), respectively, for $2 \mathrm{~h}$ at room temperature. After washing, Alexa 488 goat anti-mouse or anti-rabbit antibody (Invitrogen) was applied for $1.5 \mathrm{~h}$. Nuclei were counterstained using Hoechst 33342 (Roche Diagnostics, Mannheim, Germany), mounted and analyzed using a fluorescence microscope and Axiovision Software (Carl Zeiss AG; Oberkochen, Germany). The settings were kept identical for all samples.

\section{Gene complementation studies}

For FA complementation group determination, the cell line $\mathrm{HuH}-7$ was transduced with retroviral constructs containing full-length cDNAs of FANCA, FANCB, FANCC, FANCE, FANCF, FANCG or FANCL and analyzed for cell cycle arrest upon treatment with $M M C$ and for restoration of FANCD2 monoubiquitination, as previously described [26]. For isogenic studies, HuH-7 cells were stably transduced with either HA-tagged pMSCVFANCC (HuH-7/FANCC) or the corresponding pMSCV empty control vector (HuH-7/ev).

\section{gDNA sequencing}

High molecular weight genomic DNA was prepared using a salting-out technique. Amplification of the FANCC exons was performed using published primer sets [75]. PCR products were purified using the GFX PCR DNA and Gel Band Purification kit (GE Healthcare). DNA sequencing of PCR products was performed using ABI-PRISM big-dye terminator chemistry on the ABI 310 instrument (Applied Biosystems, Darmstadt, Germany).

\section{mRNA expression analyses and cDNA sequencing}

Total RNA was extracted from surgical HCC tissues or cell lines using the NucleoSpin RNAII-Kit (MachereyNagel, Düren, Germany). RNA was reverse-transcribed using SuperScriptII reverse transcriptase (Invitrogen) and cDNA synthesized. Aberrant splicing of FANCC was determined by RT-PCR using the following primer pairs: Fwd 5'-ACTGCCCAAACTGCTGAAG-3' and Rev 5'GTTCAGACGCTAATGATAAAACCA-3' (spanning the first non-coding exon to coding exon 5), Fwd 5'-TTCTGGACAATCAAAACTTAACTCC-3' and Rev 5'-GCTGCTGCTTCTGGACATT-3' (spanning the coding exons 3 to 13 ), Fwd 5'-GTAGTCTG CCTCTGGCTTCG-3' and Rev 5'-TTGAGGAGAAGGTGCCTGAT-3' (spanning the coding exons 7 to 13). Expression of FANCC, FANCF and FANCG mRNA was validated by RT-PCR as described previously [76]. For sequencing of the complete coding regions of $F A N C C, F A N C F$ and FANCG, respectively, the corresponding cDNAs were amplified in two (FANCF) or three (FANCC and FANCG) overlapping PCR reactions (primer sets available on request). Amplified products 
were sequenced using an ABI-Prism 3100-Avant Sequencer (Applied Biosystems) and sequence changes confirmed at the genomic level by gDNA sequencing. Reference genomic and cDNA sequences of the FA genes are available in the Fanconi Anemia Mutation Database [77].

\section{Cell proliferation assays}

The assays were performed over a broad range of concentrations covering $100 \%$ to $0 \%$ cell survival. $1,500-2,000$ cells/well were plated in 96-well plates, allowed to adhere, and treated. Following incubation for $6 \mathrm{~d}$, the cells were washed, lysed in $100 \mu \mathrm{l} \mathrm{H}_{2} \mathrm{O}$, and 0.5\% Picogreen (Molecular Probes, Invitrogen) was added. Fluorescence was measured (Cytofluor Series 4000, Applied Biosystems) and growth inhibition calculated as compared to the untreated control samples. Three independent experiments were performed per agent, with each data point reflecting triplicate wells. Error bars represent standard error of the mean (SEM) from three experiments.

\section{Cell cycle analyses}

Cells were seeded in 12-well plates and treated in duplicate for $48 \mathrm{~h}$ using various MMC concentrations (ranging from 25 to $200 \mathrm{nM}$ ) or were left untreated. The cells were fixed, stained with propidium iodide, and the DNA content per cell was measured using flow cytometry (FACSCalibur, Becton Dickinson, Heidelberg, Germany). The data were analyzed using CELLQuest Pro software (Becton Dickinson). Alternatively, unfixed cells were stained with DAPI at a final concentration of $1 \mu \mathrm{g} / \mathrm{ml}$ in a buffer containing $154 \mathrm{mM} \mathrm{NaCl}, 1 \mathrm{mM} \mathrm{CaCl} 2,0.5 \mathrm{mM} \mathrm{MgCl}_{2}$, $0.1 \mathrm{M}$ TRIS, $0.2 \% \mathrm{BSA}$, and $0.1 \% \mathrm{NP} 40$ for $30 \mathrm{~min}$ in the dark. Univariate flow histograms were recorded on an analytical, triple-laser equipped flow cytometer (LSRII, Becton Dickinson) using UV excitation of the DAPI dye. The resulting cell cycle distributions reflecting cellular DNA content were quantified using the MPLUS AV software package (Phoenix Flow Systems, San Diego, CA).

\section{Hpall restriction enzyme methylation analysis}

PCR-based HpaII-restriction assays were performed as described previously [23]. Transcriptional silencing through CpG hypermethylation was analyzed using published primer sets for FANCF [23] and FANCC [69], respectively. Primers used for FANCG were 5'-GAGTGCAATGGCACGATG-3' (forward) and 5'-GCATGCTGGGAGTCGTAGTA-3' (reverse). CpGenome universal methylated or unmethylated DNA (Chemicon - Millipore, Schwalbach am Taunus, Germany), respectively, were used as controls.

\section{List of abbreviations}

FA: Fanconi anemia; GI: gastrointestinal, HCC: hepatocellular carcinoma; ICL: interstrand-crosslink; IC50: inhibitory concentration 50\%; LOH: loss of heterozygosity; MMC: mitomycin C; SNP: single nucleotide polymorphism; RT-PCR: reverse-transcription PCR; TACE: transarterial chemoembolization

\section{Competing interests}

The authors declare that they have no competing interests.

\section{Authors' contributions}

AP was involved in study design, acquisition, analysis and interpretation of most of the data and drafted the manuscript. KN and DS carried out the complementation studies and parts of the genomic sequencing. UP, AZ, BT and DM performed and interpreted most of the immunoblotting assays. UP and AZ further performed and interpreted drug sensitivity assays and AZ additionally performed parts of the genomic sequencing. AR, EDT and AZ performed and interpreted the FACS analyses. SO performed immunoblotting, immunofluorescence and interpreted the nuclear focus formation assays. BT and FB engineered the stably transduced $\mathrm{HuH}-7$ pMSCV lines. GUD provided and analyzed cholangiocellular carcinoma cell lines. WET provided the HCC tumor specimens. $\mathrm{HH}$ provided the retroviral constructs. EDT, CS, BG and DS participated in the conception and the design of the study or provided important intellectual content. EG conceived the project, coordinated the experiments, directed the analysis and interpretation of the data and wrote the final manuscript. All authors read and approved the final manuscript.

\section{Acknowledgements}

Tissue samples were obtained and experimental procedures were performed according to the guidelines of the charitable state controlled foundation HTCR, with the informed patient's consent [78]. We kindly acknowledge expert technical assistance with flow cytometry by Richard Friedl, Würzburg. This work was supported by grants to EG (DFG Ga762/3-1, Bavarian Academy of Sciences and Arts, Förderprogramm für Forschung und Lehre, Friedrich-Baur-Foundation, K.L. Weigand Fund) and to EDT (DFG To605/2-1).

\section{Author Details}

'Department of Medicine II, Campus Grosshadern, Ludwig-MaximiliansUniversity, Marchioninistrasse 15, 81377 Munich, Germany, 2Department of Human Genetics, Biocenter, Julius-Maximilians-University, Am Hubland, 97074 Würzburg, Germany, ${ }^{3}$ Department of Medicine III, Klinikum rechts der Isar, Technical University Munich, Ismaningerstrasse 22, 81675 Munich, Germany, 4Department of Surgery, Campus Grosshadern, Ludwig-Maximilians-University, Marchioninistrasse 15, 81377 Munich, Germany and 5epartment of Pediatric Oncology, Hematology and Clinical Immunology, Heinrich Heine University, Moorenstrasse 5, 40225 Düsseldorf, Germany

\section{Received: 14 October 2009 Accepted: 28 May 2010}

Published: 28 May 2010

\section{References}

1. D'Andrea AD, Grompe M: The Fanconi anaemia/BRCA pathway. Nat Rev Cancer 2003, 3:23-34.

2. Wang W: Emergence of a DNA-damage response network consisting of Fanconi anaemia and BRCA proteins. Nat Rev Genet 2007, 8:735-748.

3. Gallmeier E, Hucl T, Calhoun ES, Cunningham SC, Bunz F, Brody JR, Kern SE: Gene-Specific Selection Against Experimental Fanconi Anemia Gene Inactivation in Human Cancer. Cancer Biol Ther 2007, 6:654-660.

4. Meetei AR, Medhurst AL, Ling C, Xue Y, Singh TR, Bier P, Steltenpool J, Stone S, Dokal I, Mathew CG, et al:: A human ortholog of archaeal DNA repair protein Hef is defective in Fanconi anemia complementation group M. Nat Genet 2005, 37:958-963.

5. Levitus $M$, Joenje $H$, de Winter JP: The Fanconi anemia pathway of genomic maintenance. Cell Oncol 2006, 28:3-29.

6. Dorsman JC, Levitus M, Rockx D, Rooimans MA, Oostra AB, Haitjema A, Bakker ST, Steltenpool J, Schuler D, Mohan S, et al: Identification of the Fanconi anemia complementation group I gene, FANCl. Cell Oncol 2007, 29:211-218.

7. Sims AE, Spiteri E, Sims RJ III, Arita AG, Lach FP, Landers T, Wurm M, Freund $M$, Neveling $\mathrm{K}$, Hanenberg $\mathrm{H}$, et al:: $\mathrm{FANCl}$ is a second monoubiquitinated member of the Fanconi anemia pathway. Nat Struct Mol Biol 2007, 14:564-567. 
8. Smogorzewska A, Matsuoka S, Vinciguerra P, McDonald ER III, Hurov KE, Luo J, Ballif BA, Gygi SP, Hofmann K, D'Andrea AD, Elledge SJ: Identification of the FANCI protein, a monoubiquitinated FANCD2 paralog required for DNA repair. Cell 2007, 129:289-301.

9. Wong AK, Pero R, Ormonde PA, Tavtigian SV, Bartel PL: RAD51 interacts with the evolutionarily conserved BRC motifs in the human breast cancer susceptibility gene brca2. J Biol Chem 1997, 272:31941-31944.

10. Yuan SS, Lee SY, Chen G, Song M, Tomlinson GE, Lee EY: BRCA2 is required for ionizing radiation-induced assembly of Rad51 complex in vivo. Cancer Res 1999, 59:3547-3551.

11. Godthelp BC, Wiegant WW, Waisfisz Q, Medhurst AL, Arwert F, Joenje H, Zdzienicka MZ: Inducibility of nuclear Rad51 foci after DNA damage distinguishes all Fanconi anemia complementation groups from D1/ BRCA2. Mutat Res 2006, 594:39-48.

12. Reid S, Schindler D, Hanenberg H, Barker K, Hanks S, Kalb R, Neveling K, Kelly P, Seal S, Freund M, et al:: Biallelic mutations in PALB2 cause Fanconi anemia subtype FA-N and predispose to childhood cancer. Nat Genet 2007, 39:162-164

13. Fackenthal JD, Olopade OI: Breast cancer risk associated with BRCA1 and BRCA2 in diverse populations. Nat Rev Cancer 2007, 7:937-948

14. Pal T, Permuth-Wey J, Betts JA, Krischer JP, Fiorica J, Arango H, LaPolla J, Hoffman M, Martino MA, Wakeley K, et al:: BRCA1 and BRCA2 mutations account for a large proportion of ovarian carcinoma cases. Cancer 2005, 104:2807-2816.

15. Murphy KM, Brune KA, Griffin C, Sollenberger JE, Petersen GM, Bansal R, Hruban RH, Kern SE: Evaluation of candidate genes MAP2K4, MADH4, ACVR1B, and BRCA2 in familial pancreatic cancer: deleterious BRCA2 mutations in 17\%. Cancer Res 2002, 62:3789-3793.

16. King MC, Marks JH, Mandell JB: Breast and ovarian cancer risks due to inherited mutations in BRCA1 and BRCA2. Science 2003, 302:643-646.

17. Goggins M, Schutte M, Lu J, Moskaluk CA, Weinstein CL, Petersen GM, Yeo CJ, Jackson CE, Lynch HT, Hruban RH, Kern SE: Germline BRCA2 gene mutations in patients with apparently sporadic pancreatic carcinomas. Cancer Res 1996, 56:5360-5364

18. Friedenson $B: B R C A 1$ and $B R C A 2$ pathways and the risk of cancers other than breast or ovarian. MedGenMed 2005, 7:60.

19. Heijden MS van der, Brody JR, Dezentje DA, Gallmeier E, Cunningham SC, Swartz MJ, DeMarzo AM, Offerhaus GJ, Isacoff WH, Hruban RH, Kern SE: In vivo therapeutic responses contingent on Fanconi anemia/BRCA2 status of the tumor. Clin Cancer Res 2005, 11:7508-7515.

20. Heijden MS van der, Brody JR, Gallmeier E, Cunningham SC, Dezentje DA, Shen D, Hruban RH, Kern SE: Functional defects in the fanconi anemia pathway in pancreatic cancer cells. Am J Pathol 2004, 165:651-657.

21. Couch FJ, Johnson MR, Rabe K, Boardman L, McWilliams R, de Andrade M, Petersen G: Germ line Fanconi anemia complementation group C mutations and pancreatic cancer. Cancer Res 2005, 65:383-386.

22. Heijden MS van der, Yeo CJ, Hruban RH, Kern SE: Fanconi anemia gene mutations in young-onset pancreatic cancer. Cancer Res 2003, 63:2585-2588

23. Taniguchi T, Tischkowitz M, Ameziane N, Hodgson SV, Mathew CG, Joenje H, Mok SC, D'Andrea AD: Disruption of the Fanconi anemia-BRCA pathway in cisplatin-sensitive ovarian tumors. Nat Med 2003, 9:568-574.

24. Tischkowitz M, Ameziane N, Waisfisz Q, De Winter JP, Harris R, Taniguchi T, D'Andrea A, Hodgson SV, Mathew CG, Joenje H: Bi-allelic silencing of the Fanconi anaemia gene FANCF in acute myeloid leukaemia. $\mathrm{Br} J$ Haematol 2003, 123:469-471.

25. Narayan G, Arias-Pulido H, Nandula SV, Basso K, Sugirtharaj DD, Vargas H, Mansukhani M, Villella J, Meyer L, Schneider A, et al:: Promoter hypermethylation of FANCF: disruption of Fanconi Anemia-BRCA pathway in cervical cancer. Cancer Res 2004, 64:2994-2997.

26. Neveling K, Kalb R, Florl AR, Herterich S, Friedl R, Hoehn H, Hader C, Hartmann FH, Nanda I, Steinlein C, et al.: Disruption of the FA/BRCA pathway in bladder cancer. Cytogenet Genome Res 2007, 118:166-176.

27. Marsit CJ, Liu M, Nelson HH, Posner M, Suzuki M, Kelsey KT: Inactivation of the Fanconi anemia/BRCA pathway in lung and oral cancers: implications for treatment and survival. Oncogene 2004, 23:1000-1004.

28. Gallmeier E, Kern SE: Genetic Pathways of Pancreatic Tumorigenesis. In "Disease of the Pancreas: Current Surgical Therapy": Genetic Pathways of Pancreatic Tumorigenesis Edited by: Beger H, Cameron JL, Matsuno S. Heidelberg: Springer Verlag; 2007.
29. Ameziane N, Chen F, Leemans CR, Brakenhoff RH, Joenje H: No evidence for FANCF gene silencing in head-and-neck squamous cell carcinomas. Cell Oncol 2009, 31:53-56.

30. Hahn SA, Hoque AT, Moskaluk CA, da Costa LT, Schutte M, Rozenblum E, Seymour AB, Weinstein CL, Yeo CJ, Hruban RH, Kern SE: Homozygous deletion map at 18q21.1 in pancreatic cancer. Cancer Res 1996, 56:490-494

31. Bryant HE, Schultz N, Thomas HD, Parker KM, Flower D, Lopez E, Kyle S, Meuth M, Curtin NJ, Helleday T: Specific killing of BRCA2-deficient tumours with inhibitors of poly(ADP-ribose) polymerase. Nature 2005 434:913-917.

32. Farmer $\mathrm{H}, \mathrm{McC}$ abe $\mathrm{N}$, Lord CJ, Tutt AN, Johnson DA, Richardson TB, Santarosa M, Dillon KJ, Hickson I, Knights C, et al:: Targeting the DNA repair defect in BRCA mutant cells as a therapeutic strategy. Nature 2005, 434:917-921.

33. McCabe N, Lord CJ, Tutt AN, Martin NM, Smith GC, Ashworth A: BRCA2Deficient CAPAN- 1 Cells are Extremely Sensitive to the Inhibition of Poly (ADP-Ribose) Polymerase: An Issue of Potency. Cancer Biol Ther 2005, 4:934-936.

34. Gallmeier E, Kern SE: Absence of specific cell killing of the BRCA2deficient human cancer cell line CAPAN1 by poly(ADP-ribose) polymerase inhibition. Cancer Bio/ Ther 2005, 4:703-706.

35. Ashwell S, Zabludoff S: DNA damage detection and repair pathways-recent advances with inhibitors of checkpoint kinases in cancer therapy. Clin Cancer Res 2008, 14:4032-4037.

36. Gallmeier E, Calhoun ES, Rago C, Brody JR, Cunningham SC, Hucl T, Gorospe M, Kohli M, Lengauer C, Kern SE: Targeted disruption of FANCC and FANCG in human cancer provides a preclinical model for specific therapeutic options. Gastroenterology 2006, 130:2145-2154.

37. Gallmeier E, Hucl T, Brody JR, Dezentje DA, Tahir K, Kasparkova J, Brabec V, Bachman KE, Kern SE: High-throughput screening identifies novel agents eliciting hypersensitivity in fanconi pathway-deficient cancer cells. Cancer Res 2007, 67:2169-2177.

38. Gallmeier E, Kern SE: Targeting Fanconi Anemia/BRCA2 Pathway Defects in Cancer: The Significance of Preclinical Pharmacogenomic Models. Clin Cancer Res 2007, 13:4-10.

39. Heijden MS Van Der, Brody JR, Kern SE: Functional screen of the fanconi anemia pathway in cancer cells by fancd 2 immunoblot. Cancer Biol Ther 2004, 3:534-537. Epub 2004 Jun 2018

40. Hucl T, Gallmeier E, Kern SE: Distinguishing rational from irrational applications of pharmacogenetic synergies from the bench to clinical trials. Cell Cycle 2007, 6:1336-1341.

41. Andreassen PR, D'Andrea AD, Taniguchi T: ATR couples FANCD2 monoubiquitination to the DNA-damage response. Genes Dev 2004, 18:1958-1963.

42. Nakabayashi H, Taketa K, Miyano K, Yamane T, Sato J: Growth of human hepatoma cells lines with differentiated functions in chemically defined medium. Cancer Res 1982, 42:3858-3863.

43. Japanese Collection of Research Bioresources [http:// cellbank.nibio.go.jp/]

44. Lohmann V Korner F, Koch J, Herian U Theilmann L, Bartenschlager R: Replication of subgenomic hepatitis $C$ virus RNAs in a hepatoma cell line. Science 1999, 285:110-113.

45. Gibson RA, Hajianpour A, Murer-Orlando M, Buchwald M, Mathew CG: A nonsense mutation and exon skipping in the Fanconi anaemia group $C$ gene. Hum Mol Genet 1993, 2:797-799.

46. Valentine CR: The association of nonsense codons with exon skipping. Mutat Res 1998, 411:87-117.

47. The Sanger Institute Cancer Cell Line Project [http://www.sanger.ac.uk/ genetics/CGP/CellLines]

48. Calhoun ES, Gallmeier E, Cunningham SC, Eshleman JR, Hruban RH, Kern SE: Copy-number methods dramatically underestimate loss of heterozygosity in cancer. Genes Chromosomes Cancer 2006, 45(11):1070-1.

49. Calhoun ES, Hucl T, Gallmeier E, West KM, Arking DE, Maitra A, lacobuzioDonahue CA, Chakravarti A, Hruban RH, Kern SE: Identifying Allelic Loss and Homozygous Deletions in Pancreatic Cancer without Matched Normals Using High-Density Single-Nucleotide Polymorphism Arrays. Cancer Res 2006, 66:7920-7928.

50. Greenman CD, Bignell G, Butler A, Edkins S, Hinton J, Beare D, Swamy S, Santarius T, Chen L, Widaa S, et al:: PICNIC: an algorithm to predict 
absolute allelic copy number variation with microarray cancer data. Biostatistics 11:164-175.

51. Wong $\mathrm{CM}, \mathrm{Ng}$ IO: Molecular pathogenesis of hepatocellular carcinoma. Liver Int 2008, 28:160-174.

52. Liew CT, Li HM, Lo KW, Leow CK, Lau WY, Hin LY, Lim BK, Lai PB, Chan JY, Wang $X Q$, et al.: Frequent allelic loss on chromosome 9 in hepatocellular carcinoma. Int J Cancer 1999, 81:319-324.

53. Seal S, Thompson D, Renwick A, Elliott A, Kelly P, Barfoot R, Chagtai T, Jayatilake H, Ahmed M, Spanova K, et al.: Truncating mutations in the Fanconi anemia J gene BRIP1 are low-penetrance breast cancer susceptibility alleles. Nat Genet 2006, 38:1239-1241.

54. Rogers CD, Couch FJ, Brune K, Martin ST, Philips J, Murphy KM, Petersen G, Yeo CJ, Hruban RH, Goggins M: Genetics of the FANCA gene in familial pancreatic cancer. J Med Genet 2004, 41:e126.

55. Rogers CD, Heijden MS van der, Brune K, Yeo CJ, Hruban RH, Kern SE, Goggins M: The genetics of FANCC and FANCG in familial pancreatic cancer. Cancer Biol Ther 2004, 3:167-169.

56. Jones S, Hruban RH, Kamiyama M, Borges M, Zhang X, Parsons DW, Lin JC, Palmisano E, Brune $K$, Jaffee EM, et al:: Exomic sequencing identifies PALB2 as a pancreatic cancer susceptibility gene. Science 2009, 324:217.

57. Gallmeier E, Hucl T, Winter JM, Kern SE: No mutations identified in the Fanconi Anemia gene BRIP1 (BACH1, FANCJ). NOGO 2005, 10:1.

58. Berwick M, Satagopan JM, Ben-Porat L, Carlson A, Mah K, Henry R, Diotti R, Milton K, Pujara K, Landers T, et al.: Genetic heterogeneity among Fanconi anemia heterozygotes and risk of cancer. Cancer Res 2007, 67:9591-9596.

59. Neveling K, Kalb R, Schindler D: Cancer in Fanconi anemia and Fanconi anemia genes in cancer. In Fanconi Anemia - A Paradigmatic disease for the Understanding of Cancer and Aging Edited by: Schindler D, Hoehn $\mathrm{H}$. Basel: Karger; 2007:59-78.

60. Alter BP: Cancer in Fanconi anemia, 1927-2001. Cancer 2003, 97:425-440.

61. Velazquez I, Alter BP: Androgens and liver tumors: Fanconi's anemia and non-Fanconi's conditions. Am J Hematol 2004, 77:257-267.

62. Johnson FL, Lerner KG, Siegel M, Feagler JR, Majerus PW, Hartmann JR, Thomas ED: Association of androgenic-anabolic steroid therapy with development of hepatocellular carcinoma. Lancet 1972, 2:1273-1276.

63. Sweeney EC, Evans DJ: Hepatic lesions in patients treated with synthetic anabolic steriods. J Clin Pathol 1976, 29:626-633.

64. Llovet JM, Bruix J: Systematic review of randomized trials for unresectable hepatocellular carcinoma: Chemoembolization improves survival. Hepatology 2003, 37:429-442.

65. Lopez PM, Villanueva A, Llovet JM: Systematic review: evidence-based management of hepatocellular carcinoma--an updated analysis of randomized controlled trials. Aliment Pharmacol Ther 2006, 23:1535-1547

66. Bruix J, Sherman M, Llovet JM, Beaugrand M, Lencioni R, Burroughs AK, Christensen E, Pagliaro L, Colombo M, Rodes J: Clinical management of hepatocellular carcinoma. Conclusions of the Barcelona-2000 EASL conference. European Association for the Study of the Liver. J Hepatol 2001, 35:421-430.

67. El-Serag HB, Marrero JA, Rudolph L, Reddy KR: Diagnosis and treatment of hepatocellular carcinoma. Gastroenterology 2008, 134:1752-1763.

68. Hess CJ, Ameziane N, Schuurhuis GJ, Errami A, Denkers F, Kaspers GJ, Cloos J, Joenje H, Reinhardt D, Ossenkoppele GJ, et al:: Hypermethylation of the FANCC and FANCL promoter regions in sporadic acute leukaemia. Cell Oncol 2008, 30:299-306.

69. Sinha SM, Singh RD, Alam ND, Roy AD, Roychoudhury SD, Panda CD: Alterations in candidate genes PHF2, FANCC, PTCH1 and XPA at chromosomal 9q22.3 region: Pathological significance in early- and late-onset breast carcinoma. Mol Cancer 2008, 7:84

70. Demuth I, Wlodarski M, Tipping AJ, Morgan NV, de Winter JP, Thiel M, GrasI S, Schindler D, D'Andrea AD, Altay C, et al.: Spectrum of mutations in the Fanconi anaemia group G gene, FANCG/XRCC9. Eur J Hum Genet 2000, 8:861-868.

71. Morgan NV, Tipping AJ, Joenje H, Mathew CG: High frequency of large intragenic deletions in the Fanconi anemia group A gene. Am J Hum Genet 1999, 65:1330-1341.

72. Rischewski JR, Gross M, Hanenberg H, Michael K, Schneppenheim R, Schindler D: Mutation Spectrum of FANCC in Europe and DHLPC-Based
Identification of a Large Deletion. In Fifteenth Annual Fanconi Anemia Research Fund Scientific Symposium Houston, TX; 2003.

73. Neveling K, Endt D, Hoehn H, Schindler D: Genotype-phenotype correlations in Fanconi anemia. Mutat Res 2009, 668:73-91.

74. Gallmeier E, Winter JM, Cunningham SC, Kahn SR, Kern SE: Novel genotoxicity assays identify norethindrone to activate $\mathrm{p} 53$ and phosphorylate H2AX. Carcinogenesis 2005, 26:1811-1820.

75. Gibson RA, Buchwald M, Roberts RG, Mathew CG: Characterisation of the exon structure of the Fanconi anaemia group $C$ gene by vectorette PCR. Hum Mol Genet 1993, 2:35-38.

76. Snyder ER, Ricker JL, Chen Z, Waes CV: Variation in cisplatinum sensitivity is not associated with Fanconi Anemia/BRCA pathway inactivation in head and neck squamous cell carcinoma cell lines. Cancer Lett 2007, 245:75-80.

77. The Fanconi Anemia Mutation Database [http://www.rockefeller.edu/ fanconi/mutate

78. Thasler WE, Weiss TS, Schillhorn K, Stoll PT, Irrgang B, Jauch KW: Charitable State-Controlled Foundation Human Tissue and Cell Research: Ethic and Legal Aspects in the Supply of Surgically Removed Human Tissue For Research in the Academic and Commercial Sector in Germany. Cell Tissue Bank 2003, 4:49-56.

doi: $10.1186 / 1476-4598-9-127$

Cite this article as: Palagyi et al., Genetic inactivation of the Fanconi anemia gene FANCC identified in the hepatocellular carcinoma cell line HuH-7 confers sensitivity towards DNA-interstrand crosslinking agents Molecular Cancer 2010, 9:127

\section{Submit your next manuscript to BioMed Centra} and take full advantage of:

- Convenient online submission

- Thorough peer review

- No space constraints or color figure charges

- Immediate publication on acceptance

- Inclusion in PubMed, CAS, Scopus and Google Scholar

- Research which is freely available for redistribution 